\title{
EDITORIAL
}

\section{A carreira universitária e a enfermagem}

Sem dúvida, uma das carreiras de maior prestígio social é a universitária, e uma das mais difíceis também. Para galgar o degrau mais alto, de Professor Titular, o profissional tem que dedicar sua vida à docência e à pesquisa, a fim de acumular os títulos que comporão seu Memorial, além de submeter-se a vários concursos.

Os títulos são obtidos à custa das horas de repouso e de lazer e, não raro, com prejuízo da saúde.

$\mathrm{Na}$ Universidade de São Paulo (USP) essa carreira é particularmente longa e penosa, por que é constituída de cinco degraus, ao invés dos três das universidades federais.

O início é semelhante: para o cargo de Professor Assistente é exigido o grau de Mestra; mas cessa aí a semelhança. Enquanto nas universidades federais só há mais dois degraus até o final da carreira, os de Professor Adjunto e Professor Titular, na USP há mais quatro: Professor Assistente Doutor, Professor Livre-Docente, Professor Adjunto e Professor Titular. Além disso, a Universidade de São Paulo não aceitou para si os benefícios das Leis $n .^{\circ} 5.802 / 72$ e 6.096/74 que, de 1972 a 1976, abriram a docente sem títulos acadêmicos, a possibilidade de inscrição em concurso de livre-docência.

No que diz respeito aos docentes de enfermagem, como é relativamente recente a passagem do curso para nível superior (1961), não há ainda uma tradição firmada de carreira universitária. Na USP foi realizado, em 1963, o primeiro concurso de Professor Catedrático por uma docente enfermeira, Glete de Alcântara. $O$ seu exemplo infelizmente 
não teve seguidores até a reforma universitária, quando passou a haver maior rigor na exigência de títulos para acesso na carreira.

A Professora Wanda de Aguiar Horta é a primeira docente desta Escola e a segunda da USP a atingir o degrau mais alto da carreira. Para nós é um marco que não pode deixar de ser registrado com satisfação e na esperança de que em futuro não remoto outras lhe sigam as pegadas.

M.R.S.P. 